\title{
Biomaterialcoatings - a challenging task studied by the molecular fragment dynamics
}

\author{
Carsten Wittekindt, ${ }^{*}$ H Kuhn \\ From 5th German Conference on Cheminformatics: 23. CIC-Workshop \\ Goslar, Germany. 8-10 November 2009
}

A special and important task in medicinal implant technology is to prevent the material from fouling or make it compatible for tissues by coating the material with functionalized lipid biomolecules. In order to rationalize the design of such new materials structural information about the film is needed. In this presentation we give an account on the investigation of coating of the tetraetherlipid GDNT on a borofluorate surface in different solvents. To gain insights into the dynamic process on the microsecond and micrometer scale we applied our recently developed Molecular Fragment Dynamics method (MFD) [1].

Aside of the size of the system and the duration of the simulation, the challenging task of the investigation lies in the divers chemical functionality of the compounds. The applied MFD algorithm is developed to resolve especially these problems. The MFD algorithm is based on the Dissipative-Particle-Dynamics method (DPD). Whereas in the DPD method the system is divided into different regions of fluid subsystems, the MFD algorithm calculates the interaction of molecular fragments.

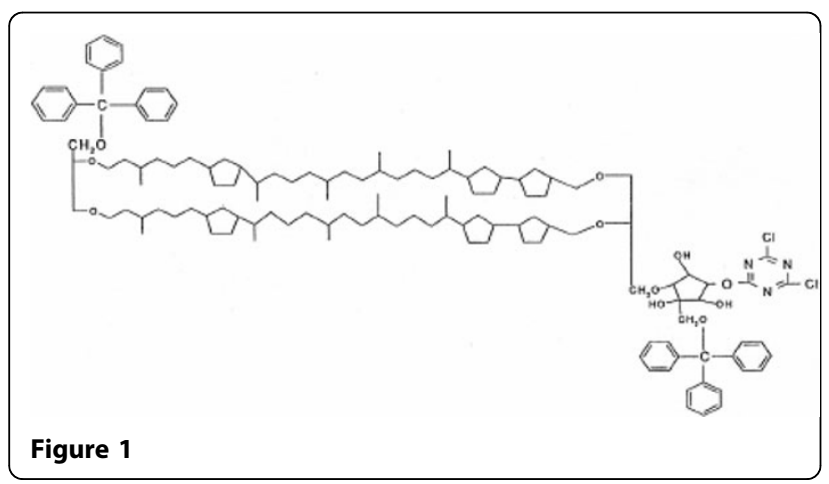

* Correspondence: wittekindt@molecular-dynamics.de CAM-D Technologies GmbH, Schützenbahn 70, 45117 Essen, Germany
Consequently, the MFD method is well suited for the molecular modelling simulation of systems having a diverse variety of chemical functionalities thus allowing for investigation of biocoatings, polymers and tensids. Figure 1.

\section{Published: 4 May 2010}

\section{Reference}

1. Ryjkina E, Kuhn H, Rehage H, Müller F, Peggau J: Molecular Dynamic Computer Simulations of Phase Behavior of Non-lonic Surfactants. Angew Chem Int Ed 2002, 41:983.

doi:10.1186/1758-2946-2-S1-014

Cite this article as: Wittekindt and Kuhn: Biomaterialcoatings - a challenging task studied by the molecular fragment dynamics. Journal of Cheminformatics 2010 2(Suppl 1):014.

\section{Publish with ChemistryCentral and every scientist can read your work free of charge \\ "Open access provides opportunities to our colleagues in other parts of the globe, by allowing anyone to view the content free of charge." W. Jeffery Hurst, The Hershey Company. \\ - available free of charge to the entire scientific community - peer reviewed and published immediately upon acceptance \\ - cited in PubMed and archived on PubMed Central \\ - yours - you keep the copyright \\ Submit your manuscript here: \\ http://www.chemistrycentral.com/manuscript/

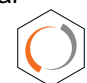 Chemistry Central}

